\title{
Does the intervention of regional authorities contribute to sustainable mangrove ecotourism? Case study on mangrove management at Karansong, West Java, Indonesia
}

\author{
Feti Fatimatuzzahroh ${ }^{1,2, *}$, Sudharto P. Hadi ${ }^{1,3}$, Hartuti Purnaweni ${ }^{1,3}$, Sudarno ${ }^{1,4}$ \\ ${ }^{1}$ Doctoral Program Environmental Science, School of Postgraduate Studies, \\ Diponegoro University, Semarang, Indonesia \\ ${ }^{2}$ Faculty Technology of Fishery and Marine Science, Nahldatul Ulama University, \\ Cirebon, Indonesia \\ ${ }^{3}$ Departement of Business Administration, Faculty of Social and Political Sciences, \\ Diponegoro University, Semarang, Indonesia \\ ${ }^{4}$ Faculty of Engineering, Diponegoro University, Semarang, Indonesia \\ "corresponding author e-mail: feti.faza@gmail.com
}

Received: 2 February 2020 / Accepted:

\begin{abstract}
Mangrove ecotourism, as one of the tools for mangrove forest conservation, indeed has a large impact on the protection of mangrove forests. This paper assesses the intervention of local authorities in the management of mangrove ecotourism by the local community. This paper used a qualitative method with in-depth interviews, using local communities' involvement, including local leaders, local resource users, and local authorities. This paper's findings show that the intervention of local authorities in mangrove rehabilitation management can cause a threat to mangrove sustainability in terms of environmental protection. The involvement of the community in the mangrove ecotourism management has become indeed remarkable. The government's intervention in the mangrove ecotourism management through a policy believed to reduce community participation. Co-management is an approach to engaging the community in mangrove management can mediate the management conflict between the local community and the government. Furthermore, the development of the relevant policy is necessary following the successful implementation of the community-based mangrove rehabilitation and preservation of mangrove forests as part of environmental protection.
\end{abstract}

Keywords: mangrove management; regional policy; local community, community involvement.

\section{Introduction}

Mangroves along tropical and subtropical coasts have substantial ecological and economic potential (Satyanarayana et al., 2012). Mangrove forest area strategically has functions to create a suitable coastal ecosystem for the aquatic organism (Emiliansa et al., 2013), such as a spawning place (Thompson \& Friess, 2019). As a unique habitat for several species (Miteva et al., 2015), it protects several plants and animal species, improving water quality and producing food and fiber roots (Lieth et al., 2008). ). In addition, mangrove forests also play an essential role in reducing wave energy, and the height of mangroves can reduce associated damage (Sulaiman et al., 2018). The ability of mangroves to control erosion (Lieth et al., 2008) in coastal areas makes mangrove a vital asset in maintain- 
ing coastal stability and protection (Harihar \& Verhagen, 2017). It also played a role in climate change mitigation (Thompson \& Friess, 2019) to absorb carbon (Miteva et al., 2015). Economically, mangroves support fisheries' various activities as a spawning ground and marine productivity to support more extensive commercial fisheries (Walters et al., 2008). Because of that role, mangrove being the key social-ecological system (Thompson \& Friess, 2019). Even with these various environmental services, mangrove damage is increasing in several worlds (Miteva et al., 2015). Mangrove loss is one of the factors causing damage to the coastal environment. Coastal environmental degradation is the most annoying issue because the threat becomes more frequent concerning global warming, which believed in causing high sea levels (Purnaweni et al., 2017).

Mangrove ecotourism has recently become a trend in coastal areas that have successfully rehabilitated. As one of the conservation tools, mangrove ecotourism has chosen as a middle way to provide mangrove education through ecotourism for people to understand mangroves' role in coastal protection. Mangrove conservation is an effort to restore mangroves' function as protectors and mitigate climate change (Thompson \& Friess, 2019). Mangrove ecotourism had a significant impact on public awareness about the importance of mangroves in coastal areas, indeed as we know that mangrove is an ecological system and a potential economy to the coastal community and the local government. Consequently, ecotourism expected to be a representation in 5\% of the world's holiday market (Das \& Chatterjee, 2015).

Ecotourism research more emphasizes on feasibility studies, sustainable community-based management, and ecotourism in terms of entrepreneurship (Kontogeorgopoulos, 2005; Foucat, 2002; Oudenhoven et al., 2015; Jones, 2005; Thompson, 2018). However, in managing community-based ecotourism, the local government policies greatly influence the sustainability of mangrove forests. The economic potential in mangrove ecotourism has to benefit the coastal community and the local government. Besides that, even the regional government looked to economic potential. Based on this potential, the conflict between community and regional government appeared in mangrove ecotourism management. As a shared resource, mangrove forests must involve the community in its management, as mentioned in community-based management. This study aims to describe community-based ecotourism management with local government intervention. What type of changes in mangrove ecotourism management due to the local government interventions. Ostrom et al. (1999) show that national governments should not reduce the decision of local communities' authority to support institutional reasons. If the government gives good feedback (appropriately appreciates) to the community effort to establish property right and institution can promote institutional sus- tainability (Datta et al., 2012). It related to decentralization right, responsibility, and local government in managing mangrove. However, the term "decentralization" or "local government" initiatives towards unsuccessful management of natural resources because of the continuous inequality and monopolized leadership structure in the institution with the result that development and social justice been hinder (Datta et al., 2012).

Research on local government policies and their implications for sustainability mangrove ecotourism is not that much. Therefore, this paper analyzes the regional government intervention by their policies in the sustainable development of mangrove ecotourism, the impact on the sustainability of mangrove ecotourism management, and community involvement in mangrove ecotourism management. This intervention impacted in community participation. The regional government hand over the right to manage mangrove ecotourism to the local community limited for five years. It is a form of co-management, as stated by Aheto et al. (2016). And based on the argument that management measures to protect and conserve mangrove forests will enhance through the recommendation of alternative management strategies such as ecosystem-based management, co-management, property rights regimes, and adaptive management (Adeel \& Pomeroy, 2002).

\section{Study Area}

Changes in mangrove conservation areas become ecotourism in Karangsong, Indramayu, West Java, which significantly impacted regional income. Later on, that matter then be the roots of the problem and conflict between community and regional government. Mangrove ecotourism has an economic benefit from Original Local Government Revenue (Pendapatan Asli Daerah/PAD). The central government looked up on the economic benefit of mangrove ecotourism as stated in regional government regulations that Original Local Government Revenue is a regional income with the amount regulated by each head of government. The change made the Indramayu regional government decide to take over the management of mangrove ecotourism. Initially, mangrove ecotourism was managed first by the Pantai Lestari group, who made a success of mangrove rehabilitation in coastal Karangsong and become mangrove ecotourism. However, based on the Decree of Regional Government Indramayu concerning tourism management, state that mangrove ecotourism management in Karangsong hand over from the Pantai Lestari group to a private sector and changing the ownership of the land in mangrove rehabilitation protecting area. The land becomes owned by the regional government Indramayu.

The regulation of mangrove management in Karangsong stipulated through the decree of Regent Indramayu 
concerning tourism management and became a conflict trigger to the community. The decree article mentions that group assignment to manage mangrove ecotourism in Karangsong did not involve the local community. Yet, the private group did not participate in mangrove rehabilitation activities before being ecotourism previously. Furthermore, it becomes a paradox, because forest policy should be a conflict resolution as a process of social negotiation to solving regulating interest rather than a conflict trigger (Krott, 2005; Kustanti et al., 2014b; Kustanti et al., 2014a).

Friess et al. (2016) argue that one of the drivers that make mangrove forest loss of a large-scale caused by policy intervention. Imprecise policy and incompatible decision management in any level of government are in contradiction with community-based management. An adequate legal framework will promote sustainable development and management of coastal and coral reefs resources. Indonesia's inappropriate legal framework has contributed to severe degradation in marine and coastal resources (Dirhamsyah, 2006). However, many regional regulations concerning fishery, mining, and sea transportation emphasize regional government income. The lack of integrated management coastal and marine resources in the area contributes to unclear and uncertain responsibility of the local government agencies function in coastal and marine sectors (Dirhamsyah, 2006). Conflict and inconsistency law also emerged on a regional scale. At least 7000 regional government regulation (Perda/Peraturan Daerah) without consultation with the central government and not in accordance with state and national policies and regulations since the enforcement of the regional autonomy (Dirhamsyah, 2006). Regional autonomy is an authority to local government to manage local natural resources and environment based on an Acts No. 22/1999 and No. 25/1999 regarding decentralization and local autonomy (Setiawan $\&$ Hadi, 2007). Many of these regulations focus on increasing regional income with little attention to conservation and sustainability (Wever et al., 2012). They exploit natural resources to increase tax revenue and regional income (Setiawan \& Hadi, 2007).

\section{Method}

A qualitative descriptive method using an integrated and sustainable mangrove management approach used in this research. The theory used is CBRNM (community-based natural resource management), with a mix of policy narratives issued by local governments with the co-management theory proposed by Aheto et al. (2016). Co-management used as an indicator to measures community involvement in mangrove management. The data was collected with indepth interviews with community people, including local leaders, local resource users, local elites, and local government representatives, to investigate mangrove management in Karangsong. Relevant documents such as research reports and journals explored to support the data.

\section{Results}

\subsection{Mangrove Management in Karangsong}

Mangrove ecotourism in Karangsong officially opened in 2015 and was inaugurated by the Indonesian Ministry of Environment. Initially, according to the Indramayu regional government's decision, Karangsong's mangrove forest area was not intended to be ecotourism, yet as a Mangrove Learning Restoration Center (PRPM/Pusat Restorasi Pembelajaran Mangrove). However, since many researchers come to analyze mangrove forests' successful rehabilitation by community groups, they made tracks to facilitate researchers during in mangrove forest. Unexpectedly, some people took e picture in mangrove tracks and made the mangrove area crowded. Moreover, it opened as mangrove ecotourism.

The Pantai Lestari group started planting mangroves to settle down the Karangsong coastal areas, which have been severely abraded and affected by losing ponds and decreasing the community's economy (Table 1). The obstacles are deltaber that had planted with mangroves and felled by the owner of deltaber to conversion with a fish pond. Therefore, the Pantai Lestari group took the initiative to bought the deltaber later to protect mangroves in the conservations area and prohibit the deltaber owner from repeatedly copping down the mangroves plant. Result of purchasing the deltaber that is mangrove conservation area developed into mangrove ecotourism. Hence, mangrove ecotourism management in Karangsong managed by the Pantai Lestari group.

According to the Indramayu district government land certificate in Indramayu District, Karangsong Village in 2010 stated that Pantai Lestari granted permission to manage and utilize the deltaber in Karangsong following Perdes (rural's regulation / Peraturan Desa) number 2 year 2009 concerning the management of mangrove protected areas in Karangsong Village with total land area up to 15 ha. The head of Karangsong rural village stated that the land area in deltaber up to 6 ha, located in Muara Sungai Song, was designated as mangrove planting activities in 2009. However, in 2017, the regional government, through the Decree of the Indramayu's Regent, created mangrove forest into the mangrove protection area and took over the management of Karangsong mangrove ecotourism under the Indramayu district tourism office. It based on the argument that the deltaber owned by the state according to Indonesian law. 


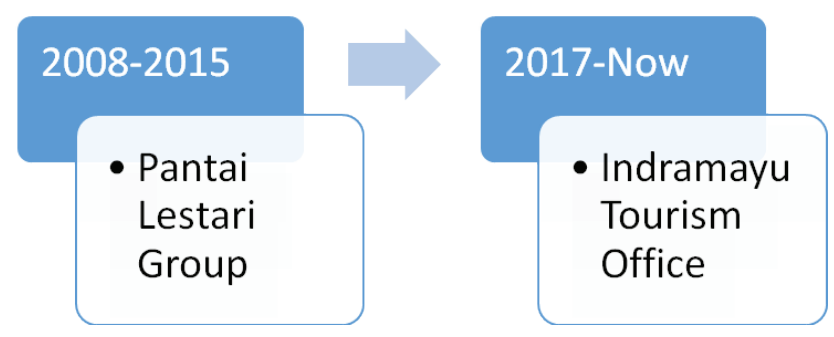

Figure 1. The Development of Ecotourism Mangrove Management in Karongsong

Agrarian Law number 5 of 2 of 1960 concerning Agrarian Principles Regulation stated that a deltaber in a coastal area will be a protecting area and stipulates as a governmental property under the National Land Agency regulations. So, the Indramayu regional government neither breaks the regulation or anything if they claim the Karangsong ecotourism area belongs to them and managed under the Indramayu ecotourism service. However, the Pantai Lestari group suing Indramayu regional government on the mangrove they planted, maintained, and developed as a mangrove ecotourism area. The lawsuit is an effort by the community to find a gap for their participation in mangrove forest management in Karangsong because the Indramayu regional government indicates the private sector whose not part of the Karangsong community or society to managed mangrove ecotourism area. Of course, that was limiting the Pantai Lestari group's participation to maintain the mangrove ecotourism area. Afterward, because of the Pantai Lestari group's lawsuit, Indramayu regional government gives the right to them to manage the ecotourism area but limited only for five years. Fatimatuzzahroh \& Hadi (2018) mention that the problems that exist in Karangsong can be an obstacle to the sustainability of the status of mangrove forests. The unsustainability of mangrove forests may cause mangrove degradation (Fatimatuzzahroh \& Hadi, 2018) because of the policies issued by the Indram- ayu government are not only the transfer of ownership of the ecotourism area but also the management.

\subsection{The impact of management changing}

There are at least two types of tourism areas in Karangsong, Pantai Song, and mangrove forests. Two different community groups manage both types. Pantai Song managed by the Mutiara Hijau group and mangrove forests by the Pantai Lestari group. Nevertheless, before entering that area, we must go through the main gate, which arranges ticketing and parking in the Karangsong tourism area. Initially, the entrance ticketing and parking in the Karangsong tourism area managed by Karangtaruna (a youth group of Karangsong village). However, since establishing the Decree of Regional Government Indramayu, ticketing and parking managed by the private sector in the end year of 2018. That impacted number of visitors in the mangrove forest area. The private sector is adding an entrance ticket per people and parking with the amount of 15.000 rupiahs. And entrance ticket to the mangrove forest area with amount 15.000 rupiahs. It has a significant impact on the number of tourists in the mangrove forest area, as show in figure 2. The decreasing of mangrove forest visitors emerging in multiplier effects such as merchantmen's income and income group or community in Karangsong.

Even the amount of ecotourist and income of mangrove ecotourism Karangsong in 2019 less than in 2015, which is 2015 , mangrove ecotourism was just opened. The community's revenue in 2019 for a year less than the income in 2015 for more or less in 6 months (see table 2)

Table 1. The Development of Ecotourism Mangrove Management at Karongsong

\begin{tabular}{|l|l|}
\hline 2008 & Mangroves planting by Pantai Lestari Group at Karongsong coastal areas \\
\hline 2014 & Mangroves were well grown and started to have strong roots \\
\hline 2015 & Defined as an Ecotourism area \\
\hline 2016 & Management and ownership is still held by Pantai Lestari Group \\
\hline 2017 & There was an issue of land ownership transfer to the Regional Government \\
\hline 2018 & $\begin{array}{l}\text { The Indramayu Regional Government lend mangrove management to Pantai Lestari Group for five years } \\
(2018-2022)\end{array}$ \\
\hline
\end{tabular}




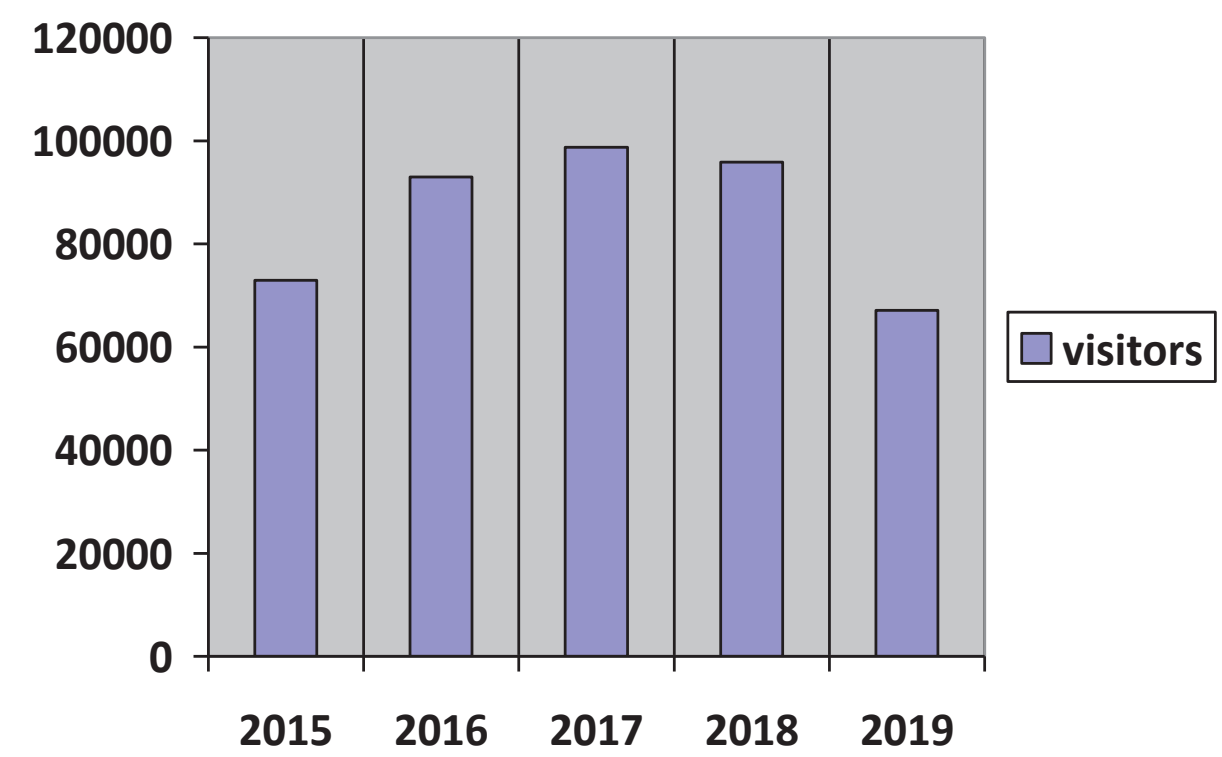

Figure 2. The Annual Amount of Ecotourist in mangrove Karangsong 2015-2019

Table 2. The income of Pantai Lestari Group in Mangrove Ecotourism (in rupiah)

\begin{tabular}{|c|c|c|}
\hline No & Year & Income \\
\hline 1 & 2015 & $1.094 .490 .000-$, \\
\hline 2 & 2016 & $1.394 .640 .000-$, \\
\hline 3 & 2017 & $1.480 .710 .000-$, \\
\hline 4 & 2018 & $1.437 .345 .000-$, \\
\hline 5 & 2019 & $1.006 .905 .000-$, \\
\hline
\end{tabular}

\subsection{Policy}

The Indramayu Regional Government policy gives management authority to third parties rather than the Pantai Lestari group in managing mangrove ecotourism areas that were considered inappropriate by the local community. This is because the policies enforced by the government should be an effort to protect mangrove ecosystems, but it seems not successful enough (Romañach et al., 2018). In addition, making mangrove management and conservation policies must pay attention to community perceptions of nature, as well as welfare as an essential criterion in the conservation of coastal ecosystems (Queiroz et al., 2017). Community participation as users of coastal resources is a principal factor in making decisions (Datta et al., 2012). Communities also make sanctions and law enforcement processes as a form of their capacity to protect sustainable mangrove resources (Datta et al., 2012). The Pantai Lestari group does this in implementing mangrove management strategy by making a Perdes (Rural Regulation/Peraturan Desa) in 2009 (Fatimatuzzahroh et al., 2018). This strategy is to protect the forest that has planted with mangroves other than paying the community strategy to participate in planting mangroves (Fatimatuzzahroh et al., 2017). Excessive tourism also can be a threat to coastal development and mangrove ecotourism. Therefore, marine life's sustainability is always a major concern in developing ecotourism (Morales et al., 2014). Because ecotourism encompassing both the welfare of the community and the sustainability of coastal ecology.

\subsection{Co-Management}

The right to manage mangrove ecotourism areas granted by the Indramayu regional government to Pantai Lestari is a co-management effort. Aheto et al. (2016) stated that making regulation and law enforcement through the local government based on the closeness with natural resources management include in co-management. Co-management emphasizes the division of authority, responsibilities, and functions of managing coastal resources to resource users as partners. In this case, Pantai Lestari, a representative of the coastal community who depends on coastal areas, has the authority and responsibility to manage ecotourism areas though they have certain limits. This shows that Indramayu regional government has an effort to involve community groups in managing the mangrove ecotourism area in Karangsong. Thus will avoid conflict interest between the local community and regional government and keep the sustainability of mangrove forest in Karangsong. Indram- 
ayu regional government and Pantai Lestai also involving CSR (Corporate Social Responsibility) from the private sector, NGOs, and academic institutions based on longterm goals and sustainability of coastal ecosystems (Aheto et al., 2016). Coastal communities that depend their lives directly on coastal resources can take collective action to protect the area. These protection efforts began when the community starts to realize the damaging mangrove habitat could threaten their lives (Aheto et al., 2016).

\section{Discussion}

The finding of this research shows that intervention local authority in mangrove management affecting the sustainability mangrove forest conservation and preservation. This finding related to Setiawan \& Hadi (2007) that the government's dominant role and the neglect of community involvement in natural resources management are the weakness in Indonesian policy. Based on an argument that the most critical factor influence in management activity is decision-making (Oudenhoven et al., 2015), the wrong decision from the local authority will affect mangrove resources' existence. Furthermore, losing mangrove forest resources and aquaculture areas means breaking the potential products and make the market pass away (Kustanti et al., 2014a; Kustanti et al., 2014b). Thus relevant to Dharmawan et al. (2016) that suggested the coastal community's contribution determines the process of successful mangrove management. What is more, community participation can restrain political change. So, the community interest will integrate with policies (Dharmawan et al., 2016).

Karangsong mangrove ecotourism is not just preservation and conservation objects, but as a development that impacts economic and social to the community. Scheyvens (1999) argues that "the most useful way to differentiate responsible community-based ecotourism is to get closer to a development perspective, which considers the results of social, environmental and economic goals. The impact of mangrove ecotourism includes a wider mandate. The characteristics of community-based ecotourism based on Walter (2011), including a. The principle of local community participation, monitoring and regulating, or having ecotourism initiatives; b. Focusing on environmental conservation and the interests of local communities; c. Promoting customary law and local culture (local wisdom); to a certain extent, d. Promote local human rights and indigenous peoples over traditional territories and resources (Reimer \& Walter, 2013). In some countries, mangrove forests owned by the government. However, monitoring and the existence of the government are often limited and even nonexistent. The majority of mangrove forests found in developing countries where government institutional ca- pacity is also weak, high social needs, and corruption are the other problem faced in mangrove management. However, the coastal area is government-owned, theoretically. De facto, coastal is an open access area with minimum monitoring toward over-exploitation and conversion to other users (Kearney et al., 2007; Primavera \& Esteban, 2008; Walters et al., 2008; Suman, 2019). That's why Comanagement is needed to anticipate the lack of community involvement in managing mangrove forests. Although in this concept, not all authority, power, and responsibility give to community groups. At least this is an effort to involve the community in managing mangrove forests under the regional government's authority.

\section{Conclusion}

Clashing between the regional government and the local community in mangrove forest management impacted mangrove conservation sustainability. This study found that the management changing, based on the Decree of Indramayu Regional government, affected the decreasing number of visiting tourists in Karangsong mangrove ecotourism. And what is more, transfer management from the community to the private sector by the policy decreases community involvement and participation in mangrove forest management. It is not appropriate with the concept of community-based mangrove management (CBMM), in which active community involvement is a principal aspect. One approach to mediate the issues is co-management. It can be an alternative to respond to regional government policy that only focuses on financial improvement without paying attention to the sustainability of mangrove forests. Therefore, more comprehensive policies needed for involving the coastal people in community-based mangrove management.

\section{Acknowledgments}

The research sponsored by the Directorate of Research and Community Service, the Directorate General of Strengthening Research and Development Ministry of Education and Culture of the Republic of Indonesia.

\section{References}

Adeel, Z., \& Pomeroy, R. 2002. Assessment and management of mangrove ecosystems in developing countries. Trees, 16(2-3), 235-238.

Aheto, D. W., Kankam, S., Okyere, I., Mensah, E., Osman, A., Ekow, F., \& Camillus, J. 2016. Community-based mangrove forest management: Implications for local 
livelihoods and coastal resource conservation along the Volta estuary catchment area of Ghana. Ocean and Coastal Management, 127, 43-54.

Das, M., \& Chatterjee, B. 2015. Ecotourism : A panacea or a predicament? Tourism Management Perspectives, 14, 3-16.

Datta, D., Chattopadhyay, R. N., \& Guha, P. 2012. Community based mangrove management: A review on status and sustainability. Journal of Environmental Management, 107, 84-95.

Dharmawan, B., Krott, M., \& Michael, B. 2016. Ocean $\&$ Coastal Management The failure of the mangrove conservation plan in Indonesia: Weak research and an ignorance of grassroots politics. Ocean and Coastal Management, 130, 250-259.

Dirhamsyah, D. 2006. Indonesian legislative framework for coastal resources management : A critical review and recommendation. Ocean \& Coastal Management, 49, 68-92.

Emiliansa, D., Samekto, A., \& Purnaweni, H. 2013. Pengembangan Kawasan Konservasi Dengan Konsep Eco Edu Wisata Mangrove Di Dusun Tapak Kelurahan Tugurejo Kota Semarang. Proceeding Biology Education Conference, 10(1).

Fatimatuzzahroh, F., \& Hadi, S. P. 2018. The Problem And Its Impacts Of Mangrove Rehabilitation In Karangsong. E3S Web of Conferences ICENIS 2018, 16(73).

Fatimatuzzahroh, F., Hadi, S. P., \& Purnaweni, H. 2017. Mangrove Cultivation Community Based in Mangrove Cultivation Community Based in Karangsong, Indramayu, West Java. IOP Conf. Series: Earth and Environmental Science, 145, 1-4.

Fatimatuzzahroh, F., Hadi, S. P., \& Purnaweni, H. 2018. Mangrove Cultivation For Dealing With Coastal Abrasion Case Study Of Karangsong. E3S Web of Conferences ICENIS 2017, 31, 1-3.

Foucat, V. S. A. 2002. Community-based ecotourism management moving towards sustainability, in Ventanilla , Oaxaca, Mexico. Ocean \& Coastal Management, 45, 511-529.

Friess, D. A., Thompson, B. S., Brown, B., Amir, A. A., Cameron, C., Koldewey, H. J., ... Sidik, F. 2016. Policy challenges and approaches for the conservation of mangrove forests in Southeast Asia. Conservation Biologi, 30(5), 1-45.

Harihar, S., \& Verhagen, H. J. 2017. Application of bamboo in mangrove rehabilitation projects. In Proceedings of the Institution of Civil Engineers - Structures and Buildings (pp. 1-16).

Jones, S. 2005. Community-Based Ecotourism The Significance of Social Capital. Annals of Tourism Research, 32(2), 303-324.

Kearney, J., Berkes, F., Charles, A., \& Wiber, M. 2007. The Role of Participatory Governance and Community-
Based Management in Integrated Coastal and Ocean Management in Canada. Coastal Management, 35(1), $37-41$.

Kontogeorgopoulos, N. 2005. Community-Based Ecotourism in Phuket and Ao Phangnga, Thailand : Partial Victories and Bittersweet Remedies Community-Based Ecotourism in Phuket and Ao Phangnga, Thailand: Partial. Jurnal of Sustainable Tourism, 13(1), 37-41.

Krott M., 2005, Forest Policy Analysis. Springer, Netherland.

Kustanti, A., Nugroho, B., Kusmana, C., Darusman, D., Nurrochmat, D., Krott, M., \& Schusser, C. 2014. Actor, Interest and Conflict in Sustainable Mangrove Forest Management - A Case from Indonesia. International Journal of Marine Science, 4(16), 150-159.

Kustanti, A., Nugroho, B., Nurrochmat, D. R., \& Okimoto, Y. 2014. Evolusi Hak Kepemilikan dalam Pengelolaan Ekosistem Hutan Mangrove di Lampung Mangrove Center. Risalah Kebijakan Pertanian Dan Lingkungan, 1(3), 143-158.

Lieth, H., Sucre, M. G., \& Herzog, B. (Eds.). 2008. Mangroves And Halophytes: Restoration And Utilisation. Netherlands: Springer.

Miteva, D. A., Murray, B. C., \& Pattanayak, S. K. 2015. Do protected areas reduce blue carbon emissions? A quasi-experimental evaluation of mangroves in Indonesia. Ecological Economics, 119, 127-135.

Morales, M. I., Masagca, J. T., Araojo, A. E., \& Vargas, S. R. 2014. Coastal and Mangrove Eco-Tourism in Catanduanes Island ( Philippines ): A Menace or a Bonus ? In International Conference on Latest Trends in Food, Biological \& Ecological Sciences (ICLTFBE'14) (pp. 42-47). Phuket (Thailand).

Oudenhoven, A. P. E. Van, Siahainenia, A. J., Sualia, I., Tonneijck, F. H., Ploeg, S. Van Der, Groot, R. S. De, ... Leemans, R. 2015. Ocean \& Coastal Management Effects of different management regimes on mangrove ecosystem services in Java, Indonesia. Ocean and Coastal Management, 116, 353-367.

Primavera, J. ., \& Esteban, J. M. . 2008. A review of mangrove rehabilitation in the Philippines : successes, failures and future prospects. Wetlands Ecol Manage, 16, 345-358.

Purnaweni, H., Kismartini, K., Hadi, S. P., \& Soeprobowati, T. R. 2017. Challenges for the Development of Resilient Coastal Area Program in Timbulsloko Village Sayung District Demak Regency. Avenced Science Letter, 23, 2582-2583.

Queiroz, L. D. S., Rossi, S., Calvet-mir, L., Ruiz-mallén, I., García-betorz, S., Salvà-prat, J., \& Meireles, A. J. de A. 2017. Neglected ecosystem services : Highlighting the socio-cultural perception of mangroves in decisionmaking processes. Ecosystem Services, 26, 137-145. 
Reimer, J. K. K., \& Walter, P. (2013). How do you know it when you see it? Community-based ecotourism in the Cardamom Mountains of southwestern Cambodia. Tourism Management, 34, 122-132.

Romañach, S. S., Deangelis, D. L., Lye Koh, H., Li, Y., Yean Teh, S., Barizan, R. S. R., \& Zhai, L. (2018). Conservation and restoration of mangroves : Global status, perspectives, and prognosis. Ocean and Coastal Management, 154(February 2017), 72-82.

Satyanarayana, B., Bhenderi, P., Debry, M., Maniatis, D., Fore', F., Badgie, D., ... Dahdouh-Guebes, F. 2012. A Socio-Ecological Assessment Aiming at Improved Forest Resource Management and Sustainable Ecotourism Development in the Mangroves of Tanbi Wetland National Park, The Gambia, West Africa. Ambio, 41, 513-526.

Scheyvens, R. (1999). Ecotourism and the empowerment of local communities. Tourism Management, 20, 245249.

Setiawan, B., \& Hadi, S. P. 2007. Regional autonomy and local resource management in Indonesia. Asia Pacific Viewpoint, 48(1), 72-84.

Sulaiman, B., Bambang, N. A., Purnaweni, H., \& Lutfi, M. 2018. The Effect of Mangrove on Fish Catch Using Belat at Teluk Pemedas and Sanipah of Kutai Kartane- gara Regency, East Kalimantan Province, Indonesia. E3S Web of Conferences ICENIS 2017, 31.

Suman, D. O. 2019. Mangrove Management : Challenges and Guidelines. Coastal Wetlands. Elsevier B.V.

Thompson, B. S. 2018. Land Use Policy The political ecology of mangrove forest restoration in Thailand : Institutional arrangements and power dynamics. Land Use Policy, 78(July), 503-514.

Thompson, B. S., \& Friess, D. A. 2019. Stakeholder preferences for payments for ecosystem services ( PES ) versus other environmental management approaches for mangrove forests. Journal of Environmental Management, 233(December 2018), 636-648.

Walters, B. B., Ro“nnba“ck, P., Kovacs, J. M., Crona, B., Hussain, S. A., Badola, R., ... Dahdouh-Guebes, F. 2008. Ethnobiology, socio-economics and management of mangrove forests : A review. Aquatic Botany, 89, 220-236.

Walter, P. (2011). Gender analysis in community-based ecotourism. Tourism Recreation Research, 36(2), 159168.

Wever, L., Glaser, M., \& Gorris, P. 2012. Ocean \& Coastal Management Decentralization and participation in integrated coastal management : Policy lessons from Brazil and Indonesia. Ocean and Coastal Management, 66, 63-72. 